Mapping peasant discontent: trespassing on manorial land in fourteenth-century Walsham-le-Willows

\author{
Author Name: Susan Kilby \\ Affiliation: University of Leicester \\ Email address: sk565@le.ac.uk \\ Word count: $\quad 7,917$
}




\title{
Mapping peasant discontent: trespassing on manorial land in fourteenth-century Walsham-le-Willows
}

\author{
Susan Kilby
}

\begin{abstract}
In recent years, it has largely been the domain of the landscape archaeologist to uncover and analyse the physical terrain of the late medieval manor. This has provided much material for the examination of ideas of rural power, control and social organisation. Considering the morphology of the settlement and adjacent fieldscape, it is rare, however, to reflect upon the views of the peasantry, who would after all have made up the majority of the population of rural communities. Using evidence gathered from fourteenth-century manorial court rolls, this study examines peasant attitudes to the rural landscape from an historical perspective through the analysis of incidences of trespass on demesne and peasant land in the Suffolk vill of Walsham-le-Willows. Unusually, these documentary sources frequently make reference to the specific location of peasant trespass allowing for a quantitative investigation that reveals something of the motivation behind these seemingly petty and notionally accidental incidents. Traditionally, cases of trespassing on neighbouring land have been considered only fleetingly by historians, since it is generally believed that many incidents were the result of accidental damage by wandering livestock, or that manorial officials used court fines as a means of licensing access. This study shows that the reality was far more complex, and that there was a range of motivational stimuli for these acts.
\end{abstract}

\section{Keywords}

Suffolk, Walsham-le-Willows, peasantry, trespass, friction, landscape, manorial court, manor

\section{Introduction}

The idea that enduring struggle existed between lords and peasants has been the focus of a number of historical enquiries. Hilton and Bloch considered the relationship between both parties to be persistently antagonistic and characterised by underlying tensions (Razi, 1983, p. 153; Hilton, 1985, p. 130). Several historians dispute this, suggesting a more generally co- 
operative experience, whilst others advocate a more local approach allowing for less universal conclusions (DeWindt, 1971, p. 270; Britton, 1977, p. 120). The manorial court rolls of thirteenth- and fourteenth-century England abound with incidences of peasant trespass. And yet historians analysing them with a view to resolving the debate concerning lordly and peasant relations have approached cases of trespass cautiously, or ignored them altogether. Where trespass has been used as evidence in manorial studies, arguments focus on peasant relationships, power structures, or more clearly definable cases of wrongdoing, such as hand-milling or poaching (E. DeWindt 1971, pp. 264-8; Britton 1977, p. 120; A. DeWindt 1976 , p. 257; Smith 2009, pp. 403-8) ${ }^{1}$. This is partly because of the problematic nature of the term itself; it covered a variety of transgressions, including trespass in the modern sense, slander, damage, and occasionally, bodily harm and the unwarranted detention of chattels (Schofield 2010, pp. 154-5). There are other, perhaps more compelling, reasons for historians' reluctance to engage with this rich seam of evidence; in particular, the difficulty of determining whether peasant trespass was accidental or deliberate (Müller 2012, p. 9; Schofield 2003, p. 161). Open fields suggest a landscape in which unintentional damage may have been the norm, especially since many peasants owned livestock which must on occasion have wandered onto prohibited territory. Additionally, it has been considered that in some instances fines for trespassing on the lord's land may denote a form of licence sanctioning peasant access to demesne land (May, 1973, p. 391). ${ }^{2}$ However, incidences of trespass in the Suffolk vill of Walsham-le-Willows (hereafter referred to as Walsham) reveal much about the motivation of peasant trespass, and indeed peasant mentalities concerning local landscape, and perhaps offer a new approach to the study of this abundant yet troublesome evidence. This study shows that a great deal of trespass at Walsham was probably deliberate, that certain motivational stimuli resulted in trespass and damage to particular places, that place and territory were important to Walsham tenants, and that some places within the localised parish landscape were more significant than others.

\section{Walsham-le-Willows}

Walsham in Suffolk, lies twelve miles from Bury St Edmunds and eight miles to the west of the sandy Breckland region, predominantly on boulder clay but with some heavier soils to 
the east (Bailey 1989, p. 131; West and McLaughlin 1998, p. 1). There were three manors in the fourteenth century, two of which will be studied here: the larger Walsham, where the

lord was absent, and High Hall, with a resident lord (Lock 1998, pp. 6-7). ${ }^{3}$ The village morphology is complex, but not uncharacteristic of the region as a whole (Jones and Page 2006 , p. 10). Landscape reconstruction suggests there were five hamlets and a green (figure one), although the main focal point for much of the period was the Church Street area containing the church and the progressively more dominant Walsham manorial complex. High Hall's manorial centre was situated in the east of the parish. The village common was at Cranmer Green, and both manors accessed another common outside the parish boundary at Allwood Green, which was also shared with other manors. ${ }^{4}$ In 1272 , an extent of Walsham manor outlined 'two windmills, 3871/2 [acres of] arable, eight [acres of] meadow and 49 [acres of] wood', indicating that meadow was scarce (Cal. Inq. Post Mortem 1906, p. 247). The medieval field system is unclear. West and McLaughlin propose six medieval open fields, but these fields only feature in the Walsham court rolls (West and McLaughlin 1998, p. 77 and p. 107), whereas a seventh field - angerhalefield - is mentioned in the High Hall rolls. There are examples of villages of divided lordship sharing a common field system, and that may have been the case here (Ault 1972, p. 75). Dymond suggests thirteen sixteenthcentury fields, and so perhaps Everitt's assertion - that extensive commons were normal in landscapes of dispersed hamlets with multiple open fields - fits well with a more complex morphology (Dymond 1976, p. 204; Dodd 1974, pp. 49-158; Everitt 2000, p. 214).

\section{Sources and data}

A great quantity of manorial documentation survives, the most pertinent of which for the purposes of this enquiry are lengthy runs of manorial court rolls, and for Walsham manor, courts general. ${ }^{5}$ The surviving fourteenth-century court rolls for the two Walsham manors considered here have been translated in two volumes (Lock 1998; Lock 2002). Servile peasants were bound to attend the manorial court, which was notionally presided over by the lord. ${ }^{6}$ Theoretically, the court sat every three weeks, but in many places it was held much less frequently. The vagaries of court roll survival mean that is difficult to determine how frequently the two Walsham courts were convened, but between 1316-1345, the mean 
average number of courts annually held in each manor was just two. ${ }^{7}$ This study is only concerned with those court cases that clearly reference unauthorised entry and possible damage to the lands of another. This encompasses relevant cases of trespass - Latin transgressione-, usually presented through a personal action between one tenant and another, with a view to the litigant recovering suitable damages; and also relevant cases of damage on the lord's land - Latin dampnum - generally brought to the court's attention through a presentment jury, who were required to answer questions concerning local violations and trespasses set by the steward (Beckerman 1992, p. 228; Schofield 1998, p. 28; Briggs 2006, p. 553). There are many examples of the jury or homage concealing action of this type throughout English court rolls of this period, and so in some instances, presentments may have been made grudgingly.

The substantial number of cases forms a statistically significant body of data despite the typical gaps within manorial sources of this nature (table 1). It is usual to attempt comparison with another vill or manor, but this is difficult because of the great detail contained with the Walsham court rolls. The locational aspects of peasant trespass elsewhere are not usually recorded in the quantity expressed within the Walsham records. Therefore, in order to provide a comparative framework, two chronological periods were analysed: 1316-1345 and 1369-1398. Both cover important local and national events. The earlier period encompasses the Great Famine of 1315-18, the subsidy return and Bury St Edmunds' riots of 1327, and the Lay Subsidy of 1334; the later period covers the Peasants' Revolt and the poll tax of 1381. Throughout, although a large volume of court rolls survive, there are some gaps. ${ }^{8}$ Only incidents that can be firmly associated with the landscape have been assessed. ${ }^{9}$ In all, there were 1,352 transgressions of this type between 1316-1345, and 508 between 1369-1398, as outlined within table 1 . This significant drop noted in the later period may not represent the weakening authority of the lord, but is probably explained through the reduction by more than half in the number of surviving court rolls for the later period. ${ }^{10}$ Certainly, elsewhere, others have noted an increase in court presentments at that time (Dyer 1984, pp. 28-9; Larson 2006, p. 131). In 1998, West and McLaughlin undertook a meticulous reconstruction of Walsham's late medieval landscape, allowing detailed examination of specific locations mentioned within the court rolls, and this work allows for an emphasis on the landscape in the analysis undertaken here. 


\section{Seigneurial perceptions of the local environment}

In many late medieval images, artists - presumably in order to please their elite patronsdepicted seigneurial assets such as dovecotes, mills, warrens and parks as distinctly separate from peasant space, and as such, they were visualised as devoid of peasants. In the Luttrell Psalter, peasants are absent from the lord's several fishery adjacent to the water mill, in the warren and the garden. ${ }^{11}$ This view is frequently corroborated by archaeological evidence where it has been shown that lords might manipulate the manorial environment either through the planning of settlements, or via their reconfiguration, often re-siting peasant tofts (Faith 1997; Altenberg 2003; Jones and Page 2006). Roads might also be closed or diverted to suit lords. In mid-thirteenth-century Pinley (Warwickshire), Geoffrey de Langley, a minor secular lord, obtained royal assent to enclose a footpath and forbade its use henceforth; other paths were diverted, and new ones created as he sought to reorganise his manor (Coss 1991, p. 108). And in fourteenth-century Lillingstone Lovell (Oxfordshire), the main village street was redirected following the re-siting of the manorial complex (Jones and Page 2006, p. 162). As scholars from across many disciplines have attested, lords frequently attempted to control the landscape, often taking a planned approach to settlements, even in rural areas. ${ }^{12}$ In this period, servile peasants were legally bound to the land of the manor to which they belonged. They were required to provide customary services to the lord although many were commuted for cash payments by the fourteenth century - and were notionally unable to leave the manor without the lord's permission. As writers like Hill and Freedman have shown, in many contemporary images - in particular in calendars like the Très Riches Heures, and in marginal art in works like the Luttrell Psalter- peasants were firmly connected with the soil, and although this was a period of increasing migration, those living in rural manors were largely dependent on the land for both their livelihoods and their subsistence (Hill 1993, p. 27; Freedman 1999, pp. 143-4). So, despite these texts' elite provenance and their bias toward the seigneurial perspective, they accurately depict a strong -if potentially ambivalent- peasant connection to and identification with the land. In modern communities where residents' lives are intrinsically bound to the land, the connection between the landscape and the husbandman is palpable: in a recent newspaper report, a Palestinian olive farmer threatened with displacement ardently declared 'our life, our identity is in the land', an example that emphasises the strength of feeling. ${ }^{13}$ 


\section{Peasant perceptions of the local environment}

In order to consider the possible motivation behind peasant trespass on and damage to the lord's land, it is first worth examining intra-peasant conflict. In fourteenth-century Walsham, land was frequently the focus of dispute. In 1334 John Man and William Wodebite engaged in an intense series of reciprocal damage to each other's gardens and crops. John Man -or, possibly his livestock, although they are not mentioned- trampled Wodebite's oats and wheat, and even the vegetables growing in his garden. Wodebite reciprocated by letting his pigs loose in Man's courtyard and in his barley and oats. Following this, Man destroyed more of Wodebite's wheat, and the whole saga culminated in William Wodebite being fined a penny 'because his horse bit John Man's horse' (Lock, 1998, pp. 180-1). Despite the unusual conclusion to this affair, there is a serious point worth noting: these men were clearly locked in an intense neighbourly spat, the elected response to which was to damage each other's crops. This demonstrates that trespass and damage could, on occasion, be used as a physical expression of conflict and quarrel. The same court roll confirmed that John Man would continue leasing all the lands of the recently deceased John Wodebite, for three years. Were these incidents the result of a dispute over the Wodebite family's suspended inheritance mentioned in the same court roll? Similarly, in a dispute between John Hawys and John Coggeshall in 1397, Hawys was fined following an enquiry into several counts of the detention of Coggeshall's cash and goods. He was separately amerced for trespass against Coggeshall, taking sixteen sheaves of barley and beating a pig. In the same roll, John Coggeshall was fined in a plea of trespass for detaining cash and trespassing in Hawys' corn, bullimong and peas, of which for the latter Hawys' loss was valued at $4 \mathrm{~s}$. $6 \mathrm{~d}$. Finally, the same roll records an enquiry following a plea of trespass, into whether Coggeshall 'broke the hedge of John Hawys'. In the next court, he was found guilty and fined 2d. (Lock 2002, pp. 198-200). ${ }^{14}$ Again, we seem to see a natural response to conflict being expressed through petty acts of theft and damage to standing crops.

Similar acts were repeated by other tenants throughout both periods, but they appear less unusual when considered alongside ideas concerning peasant identity: these actions were surely designed to strike a blow against that which was considered most important of all: crop-producing land, and therefore, perhaps peasant identity itself. Despite the correlation between peasant identity and land, many historians have not connected 
trespass on and damage to neighbouring land with wilful intent in the same manner in which poor productivity and customary labour, or the refusal of labour services and opposition to the lord are frequently coupled (Dyer, 1994, p. 7; Stone, 1997, p. 641; Müller 2003, p. 1; Schofield, 2003, p. 160). ${ }^{15}$ This is perhaps because emphasis has been placed on events surrounding larger peasant movements, like the Peasants' Revolt. But sociologists studying modern peasant communities argue that undetectable acts, the 'patient, silent struggles' of peasants against their lords, described by Bloch, are as valid as mass movements and should, in the case of trespass on and damage to the lord's land, be treated as passive acts of resistance to power (Bloch, 1966, p. 170; Guha, 1983, p. 82; Scott, 1985, pp. 28-9; Scott, 1987, p. 419). And so perhaps peasant trespass that can be conclusively linked with damaged crops should be re-evaluated.

\section{Negotiating the local environment}

The historical geographer Dodgshon considered spatial order and the perceived control by lords over subordinate peasants to be the direct result of principles of feudalism. Importantly, he argued that the landscape became divided into a chequerboard on which occupation was legitimised in some spaces but not others' (Dodgshon 1987, p. 167 and p. 192). Considering the configuration of the medieval vill, the archaeologist Saunders supported this idea, emphasising the political nature of the planned settlement through lords' attempts to observe, restrict and regulate peasant movement (Saunders 1990). Settlement re-modelling can be traced from the ninth century; however, a wave of lordly replanning at the end of the twelfth century separated elite and peasant spaces more overtly in many places (Faith 1997, p. 201; Jones and Page 2006, p. 183). These modifications were coincident with changes taking place in the common law, after which peasant status was formalised. As Harvey has argued, it was at this point that seigneurial focus shifted away from the idea of tenurial relationships with individuals toward consideration of land in terms of tenements. As he suggests in 1100 the lord of a manor was the lord of men who held lands of him; in 1200 he was the lord of lands that were occupied by tenants' (Harvey 1984).

Dodgshon's and Saunder's arguments are valid in part: undoubtedly they capture the essence of seigneurial mentalities behind the switch in emphasis towards a greater focus on tenement rather than tenant. However, they fail to evaluate lords' success in their 
attempts to regulate and control peasant movements through the manorial environment, and to ascertain the peasant view of these impositions, and have essentially taken the position adopted by late medieval lords - and disseminated in written sources and illuminations - at face value. ${ }^{16}$ The sociologist Lefebvre astutely notes that 'visible boundaries, such as walls or enclosures in general, give rise for their part to an appearance of separation between spaces where in fact what exists is ambiguous continuity' (Lefebvre 2009 , p. 87). In other words, from the perspective of late medieval peasants, the impediment of a network of constraints imposed upon them by elites may not have been viewed in quite the way lords intended. Even if the implicit impression suggested by elite images of the manorial environment is correct - that peasants ought to be discouraged from entering certain spaces - the reality was far more complex. Lords frequently leased demesnal resources to local peasants: at Lakenheath (Suffolk), the vast majority of the Prior of Ely's extensive demesne fisheries were in the hands of local peasants in the fourteenth century, and this was not uncommon generally (Kilby 2013, p. 171). The overall impression is that peasants needed a valid reason, or perhaps even a licence in order to enter particular demesnal areas. To a certain extent, this appears to have been true, however this rarely seemed to deter local peasants from crossing the lord's private lands irrespective of whether or not they had permission to do so.

Before turning to the evidence of trespass at Walsham, it is helpful to understand how lordly space may have been perceived by medieval peasants. The idea that spatial relations within the manorial landscape were grounded in lordly power and control, with clearly defined spaces in which peasant access was either allowed or denied has been considered too rigid a structure by some. Operating within this framework were 'multiple overlapping and intersecting socio-spatial networks of power' in which some peasants, most notably manorial officials, had greater or lesser power (Mann, 1986, p. 1). Sociologist Anne Buttimer sees space as intrinsically linked to the formation of ideology and identity, an idea that accords well with the notions of both seigneurial and peasant identity outlined above (Buttimer, 1980, pp. 25-6; Altenberg, 2003, p. 24). Nevertheless, the restricted aspects of manorial landscapes must be considered if we are to unite ideas about space, identity and resistance. In Walsham, the accounts of trespass identify spaces that were ostensibly forbidden to peasants, such as the warren and the dovecote. But even within other elite 
spaces, only regulated access was usually encouraged. At Montaillou in France in the thirteenth and early fourteenth-century, the peasants rarely expressed ill-feeling toward the lord, and although obligations were often less onerous in a pastoral environment, it is perhaps significant that as pastoral farmers they enjoyed virtually open access to a considerable area of pastureland (Le Roy Ladurie, 1990, p. 19).

\section{Trespassing on the lord's land}

Manorial court rolls reveal that peasants were not averse to treating what was ostensibly seigneurial space as if it were common land, albeit perhaps in a more clandestine manner. This is most apparent through acts of poaching, but it is possible to develop the idea further by assessing other incidences of trespassing on the lord's land. This includes prohibited spaces within the settlement, but frequently features trespass in the fields beyond the vill arguably space within which some peasants had legitimate access, as they provided labour services to the lord. Generally, trespass considered in this modern sense has been avoided by many historians, largely because of the difficulty of determining whether peasant trespass was accidental or deliberate, or whether the payment of a fine essentially authorised peasant access. However, a detailed analysis of the Walsham incidents, alongside consideration of the motivational impetus behind some intra-peasant trespass noted above, offers some interesting insights into peasant trespass on the demesne. Assessing the various trespass locations is illuminating. In the years in which there is a marked increase in trespass and ensuing damage, the focus centred on arable land, and figure two outlines two such periods. It is possible that manorial officials were more alert to potential trespass on the arable. However, it is also possible that some of these acts were politically motivated, and directed against the lord. Perhaps the peasants deliberately chose to focus their efforts in damaging what they believed to be the most important accessible element of the lordly landscape.

The Man-Wodebite and Hawys-Coggeshall disputes have already emphasised the importance of crop-producing land. Anti-seigneurial trespass and damage of this nature would be more likely to have been seen as accidental than would an open attack on the manorial complex. This action fits neatly within the range of passive actions undertaken by 
peasants in modern societies, and also with the idea that accessibility affected spatial organisation: open fields were the only seigneurial spaces designed to be easily accessed by all peasants. Another crucial point is that between 1316-1345, 47 per cent of destruction to the demesne generated by trespass was not recorded as having been caused by livestock; increasing to almost 60 per cent when isolating cases in which cereals were damaged, and 70 per cent where beans and peas were trampled. Consequently, accidental damage caused by itinerant livestock seems not to have been the principal reason for the majority of trespasses at Walsham in this period. This is demonstrated by a 1316 case involving Matilda Gilbert, who was fined 14d. 'for damage done in the lord's corn', in this instance we are told that she carried away a bushel of barley and a peck of beans (Lock 1998, p. 35). Other cases indicate that peasants were making illegal paths, and driving their carts over demesne land. These are not isolated incidents; however, it is possible that some of these cases did involve untended livestock which went unrecorded. Manorial court rolls can occasionally be frustrating in the extreme in offering a glimpse of the events in question, but leaving historians guessing at the full story. But we know that not all cases concerning damaged crops were due to straying animals, and so it is worth considering that a reasonable quantity may relate to damage caused by the feet and cartwheels of peasants taking shortcuts or demonstrating little concern for demesne crops.

An assessment of key fourteenth-century events reveals some correlation with increased rates of landed trespass at Walsham, although spikes in activity do not always correspond perfectly with some of the most important events. As figure two shows, there was a marked increase in trespass on arable land toward the end of the Great Famine. Does this denote a firm increase in peasant activity, or might it represent a more tightly focused vigilance on the part of the manorial officials following an exceptionally difficult period during which crop yields plummeted? An intensification of activity is also apparent at times when there were later outbreaks of plague, particularly in 1374 , and this again might point to heightened vigilance from officials. Increases are also apparent in years in which lay subsidies and other taxes were collected. There appears to have been an increase in 1327, a year in which many peasants were taxed by the Crown, and rioting was reported in nearby Bury St Edmunds (Hallam, 1988, pp. 850-1). Although a decrease in activity was recorded in 1337 , it is noteworthy that most of the damage from trespass in that year occurred from 
September onward, the same month in which the lay subsidy was levied. Furthermore, in 1338 there were high incidences recorded in January, a month in which very few instances of this type of trespass were noted across the whole period, suggesting that 1337-8 may have been a time of unrest. This is supported by the fact that between 1316-1345, the highest fines issued by Walsham court were predominantly recorded in 1337 . These figures may be misleading, especially given the missing Walsham rolls for 1319-26, and it is difficult to link increases in trespass activity with wider events conclusively, however, the possibility cannot be discounted.

One means of recognising potentially deliberate damage is to consider group action, which within the context of peasant refusal to perform customary labour services has already been acknowledged by historians as a political act (Franklin 1996, p. 174). Across both periods, group activity is apparent, and at Walsham it is possible to identify group trespass activity taking place over lengthy time periods. Here, groups are defined as individuals operating together in the same physical location on more than one occasion, as outlined in table two, which outlines 'potential' and 'core'; core groups being identified when perpetrators appeared together in the same location more than once and are therefore more firmly acknowledged as a group. As expected, post-Black Death, the number of groups diminished as the population fell by $45-55$ per cent (Lock, 1998, p. 1). In the earlier period under review, five out of a total of eight group activists recorded as offending more than four times also numbered amongst the most frequent offenders overall. And in the later period, all four activists offending four or more times appear amid the worst offenders, outlined in table three. However, in the earlier period, these main protagonists were also more likely to have refused labour service at some point when compared with those featured in the later period; this appears further indicative of possible political intent.

Overlaying these data with the locations in which these transgressions took place, similarities and differences begin to emerge, as outlined in table four. In both periods, the majority of group and individual activity took place in the same locations, with the notable exception of ladyswood, which featured frequently in individual trespass action, but rarely as part of group action. And in both periods, the court rolls for Walsham manor suggest the main focus for trespass was wood and meadow, whilst at High Hall it was principally arable. This is not because High Hall lacked a wide range of resources: woodland transgressions, 
some associated with lenerithsdel, appear in the record, although it is likely that the ladyswood acreage was greater and thus more attractive. In fact in both manors, meadow was scarce, with High Hall tenants sharing micklemeadow, situated in the heart of Walsham land. In the later period, incidents centred on far fewer locations, and indeed chiefly on the area surrounding High Hall itself. These trespasses dated from 1380 and it is notable that the two manors were merged in 1379 (Lock, 2002, p. 12).

Figures three and four outline the areas in which the most frequent trespass and damage occurred on each manor, and in each period respectively. ${ }^{17}$ This is especially interesting when compared with the remaining identified areas in which trespass occurred across both periods (table 5), as it shows a concentration of incidents in a small number of locations. Generally, there was widespread trespass across the lands of both demesnes, implying that the areas where the most frequent activity was recorded potentially held more significance for local peasants. When further complexity is added by assessing the location of the majority of thefts from the lord at this time, ladyswood featured prominently, suggesting that its resources of timber, branches and brushwood were very attractive to people in the locality. In July 1339, four men were amerced for cutting down and selling nearly sixty ash trees, and although the quantity in this instance was unusually great, the activity was certainly commonplace, both at Walsham and more generally, as attested by manorial court rolls of this period throughout England (Lock 1998, p. 235).

The reverse was true of the trespass on High Hall land between 1316-45. Overwhelmingly, it occurred in the demesne arable. This must be considered in light of peasant connection with the land, its extreme importance to them, and their frequent inclination to resort to destroying neighbour's crops as a means of inflicting damage, as revealed through pleas of trespass recorded in the court rolls and the examples outlined above. Assessing the court fines levied for incidents of this nature, the lords of High Hall imposed the heaviest fines issued across the period, despite both manors showing modal fines of $3 \mathrm{~d}$. The great majority were levied in 1319, a year already identified as having one of the highest rates of trespass and damage for the whole period. This further suggests that incidents in 1319 were deliberate. The lord of High Hall was resident, and perhaps this influenced peasant action. Despite the focus on demesne arable lands, much of the damage 
in the earlier period occurred close to the parish boundary. Was this deliberate peasant policy designed to avoid being observed by keeping away from the manorial complex?

This is especially significant upon reviewing the later period: most of the damage was recorded taking place considerably closer to each respective manorial complex, particularly at High Hall. In fact, from 1380 onward, soon after the manors merged, incidences of trespass on High Hall demesne land close to the manorial centre soared. This might be partly explained by the farming out of the demesne some time before 1391, but the court rolls clearly indicate damage committed against the lord rather than a tenant farmer (S.R.O. HA504-3-3; Lock 2002, pp. 173-7). Nevertheless, the trend toward trespass and damage near to the manorial complex is clear. Fundamentally, the period's most prolific transgressor, Peter Robhood, only accounts for 30 per cent of damage to High Hall demesne lands between 1380-1398, suggesting this part of the landscape also held significance for others. Certainly, during this period manorial organisation was in disarray, and disobedience was frequently the norm (Fryde and Fryde 1991, p. 750). Returning to the idea that, for Saunders the 'spatial morphology of the...nucleated village was...an essential element in the lords' extra-economic means of coercion', as Walsham was dispersed, frequent legitimate occupation of the manorial complex would have been less practicable for most peasants, further supporting peasant occupation of the space after the resident lord had gone. Its moated aspect additionally suggests distinct lordly space, and the demarcation of territory (Saunders 1990, p. 187; Biddick 1990, p. 15). The High Hall manorial complex was undoubtedly associated with its erstwhile resident lord. Might it then follow that after its union with Walsham manor, peasants expressed their disrespect in the most appropriate manner: through damage to the land most closely connected with the physical symbols of manorial lordship -the manorial complex itself- and High Hall, with its moated manor house epitomised this perhaps more than any other of Walsham's seigneurial sites. In both periods, many significant scenes of trespass were furlongs apparently named by or associated with authority. Doucedeux and launde are French rather than vernacular, and ladyswood, High Hall and churchgate are names of authority. 


\section{Assessing individuals' damage and trespass: frequent offenders}

Trespasses by individuals can be informative. William Hawys committed 24 recorded acts of trespass or damage against the lord between 1316-43, and was the fourth most frequent offender across this period, the majority being presented in High Hall court. Hawys offended repeatedly as part of a group, and without exception, all these offences were carried out in the easternmost sector of the parish. Yet, tracing those of Hawys' holdings that it is possible to locate, many of his surrenders and acquisitions related to land in either the south-west or the north of the parish (figure 5). This hints at more deliberate action on demesne lands, rather than accidental damage as a result of working on his own adjacent holdings. In 1327, Hawys paid 4s. tax, one of the highest levied in Walsham (Hervey 1906, p. 183). And in 1328, he was accused of destruction in the lord's wood, and fined half a mark. This was later found to have been an unjustified accusation (Lock 1998, p. 111). Did the threat of heavy fines and high taxes impact on his behaviour and subsequently provoke him to petty acts of trespass and damage? Certainly, his trespassing increased exponentially after 1327, and he is recorded as damaging demesne land throughout the 1330 s and early 1340 s.

In the later period, Peter Robhood was by far the most prolific offender, committing 27 recorded trespasses against the lord (figure 6). Presumably his name refers to the legendary hero - did his neighbours think of him as a daredevil outlaw? Of particular interest, however, is Robhood's treatment of the Typetot inheritance which he acquired through his wife, Catherine Typetot. The acquisition itself seems questionable: having agreed the heirs as Elias and Nicholas Typetot, the court 'being better informed' surrendered the holdings to Robhood (Lock 2002, pp. 158-9). An antagonistic relationship developed, with Robhood allowing the holding go to waste, followed by reciprocal pleas of trespass including Robhood's unauthorised occupation and tilling of additional land belonging to the disinherited Typetot (Lock 2002, p. 199). This action culminated in the whole homage being ordered 'to place bounds between the...land of Walter Robhood [Peter's brother] and...Nicholas Typetot...under penalty of 20s.' due to mounting interfamilial animosity (Lock 2002, p. 208). Peter Robhood seemed perfectly aware of the incendiary nature of his actions in wasting land that the Typetots considered to be theirs. Peter Robhood is unusual in that his behaviour was polyfocal: whilst in dispute with the Typetots, he also committed seemingly anti-seigneurial trespasses centred predominantly 
on High Hall, but was also one of only a handful of peasants to be caught poaching in the lord's warren, and frequently forcibly recovered his livestock from the pound. Robhood seems to have used space in an authoritative way; he rarely seems to have refrained from accessing ostensibly forbidden places, and used his own landholdings in attempting to subdue and intimidate others. As figure six shows, he was caught causing damage to demesne land at High Hall on twelve separate occasions, suggesting that his actions were deliberate and vindictive.

\section{Assessing individuals' damage and trespass: infrequent offenders}

In any study seeking to determine the likelihood of intentional trespass, it is necessary to consider the actions of individuals who appear less prominently in the record. Gilbert Helpe was caught just five times, all but one of these offences relating to damage caused; three occurrences in the seemingly-turbulent 1319, and once each in 1329 and 1333 (Lock, 1998, pp. 81-160). In 1319, he was given the highest fine for damage to be recorded at High Hall, a staggering 6s. 8d., suggesting his 1319 trespasses were probably considered to be malicious (Lock, p. 81). In 1330 and 1333 he was openly contemptuous of the lord in court. The significance of this is that in 1333 he was fined 20s. for 'various trespasses and contempt', and in the same year he was amerced for trespass in the warren, the only year that he was caught trespassing on Walsham land. Yet he was not overburdened with customary labour or rents when compared with his peers, although he served in various manorial offices more frequently than most. On these occasions, was Gilbert's resentment of the lord revealed?

Another group of peasant families featuring infrequently in the court rolls for this type of infraction appeared to damage demesne land in the vicinity of their tenements and landholdings. Spanning both periods studied, the various family members were amerced for causing damage four times (table 6). When the manorial documents are reviewed, it is clear that these families' lands and tenements were close by, and in these cases the damage is perhaps more likely to have been accidental (figure 7), especially when compared with William Hawys infractions. The families lived in Upstreet. John Patel held a cotland; Simon Peyntour held a garden next to William Clevehog; and Elias Typetot had a garden next to Walter Qualm, who was a tenant of the tenement Clevehog, and also held land in 
peyntersyard, wellfield, angerhale and le syke, all within the south-east quadrant of the parish (Lock, 1998, p. 198, p. 233, p. 293, p. 300 and p. 317; Mclaughlin, 2007, pp. 702). John Patel, John Bolle and Elias Typetot all held pasture or meadowland in hordeshawe (Lock, 1998, p. 65; Lock, 2002, p. 35 and p. 117). The Peyntours, Qualms and Typetots had also held land in micklemeadow, albeit much of it was later surrendered, and yet they were never recorded as having trespassed there. It seems as though these neighbouring families traditionally worked together as a group; in 1318, members of the Clevehog, Typetot, Peyntour and Qualm families were amerced for what appears to have been accidental damage to another peasant's herbage. Certainly, there is none of the sustained reciprocal damage often associated with wilful inter-peasant conflict (Guha, 1983, p. 279). Yet in 1329, the whole homage 'ha[d] a duty to distrain in the lord's meadow and in the field at hordeshawe for the unlawful sowing there by various people of the neighbourhood, and to reply concerning the damage'. The concealment of this action suggests it was demesne land that was sown, possibly constituting another form of open passive resistance (Lock, 1998, p. 126; Wickham, 1998, p.5). In terms of spatial analysis, these peasant families clearly used space territorially, choosing to surrender their western-most holdings in favour of acquiring land close to Upstreet. This account supports Altenberg's emphasis on the importance of personal identification with territory, which perhaps motivated peasant trespass as much as a strong negative association with authority, an idea corroborated by the territoriality of peasant insurgency in colonial India (Guha, 1983, p. 279).

\section{Conclusion}

The detailed nature of the Walsham court rolls, alongside the reconstruction of the local landscape undertaken by West and McLaughlin has enabled a comprehensive examination of the spatial patterns of peasant trespass and damage in the medieval period to be undertaken for the first time. Through the combined study of modern peasant societies alongside the manorial records of fourteenth-century England and its landscape, it is possible to construct a clearer understanding of medieval peasant mentalities concerning land, territory, identity and resistance. As this study shows, an emphasis on the more prosaic peasant actions, hitherto considered problematic and ambiguous by many historians, offers insights into the motivation for deliberate damage of both demesne land 
and peasant holdings. This is especially significant considering peasants' strong association and identification with land itself, from both legal and socio-economic perspectives. Notwithstanding the obvious accidental nature of some peasant trespass and damage, it is possible to detect evidence for more deliberate acts. The court rolls reveal a long history of intentional intra-peasant damage, which analysis has shown to be evident elsewhere. This demonstrates that deliberate damage to both arable and pastoral land was used as part of a range of peasant responses to conflict and resentment. The high incidence of trespass on and damage to demesne arable land, frequently perpetrated by peasants rather than livestock, and occasionally using carts and creating paths, is at best suspicious. It seems hardly likely that lords would licence access through fields with standing crops -the dates of the court rolls confirm that this must have frequently been the case. Analysis of incidents of this nature in Lakenheath (Suffolk), Elton (Huntingdonshire) and Castor (Northamptonshire) show a similar pattern, whereby in a number of instances the possibility of licencing access can be discounted (Kilby, 2013, pp. 264-279). When the Walsham incidents are assessed alongside local and national events correlative effects cannot be discounted, and it seems likely that a great deal can be classified as intentional. The idea that 'place' has symbolic meaning is well known. By firmly associating deliberate trespass and damage with particular places, were Walsham's peasant community making a collective coded statement about passive resistance that was not easily read by the lords of the manor?

\section{ACKNOWLEDGEMENTS}

I would like to thank Professor Chris Dyer, Dr Richard Jones and Dr Stephen Mileson, all of whom have commented on an earlier draft of this paper. I am also very grateful to the anonymous reviewers, both of whom made helpful and thought-provoking comments, which have undoubtedly improved the finished article. I would also like to thank $\mathrm{Mr}$ Brian Turner of the Walsham History Society for offering me copies of various helpful documents and reading material. 


\section{PRIMARY SOURCES}

Calendar of Inquisitions Post Mortem and Other Analagous Documents Present in the Public Record Office, Vol. II, Edward I (London, 1906)

R. Lock (ed.), The Court Rolls of Walsham le Willows, 1303-50, Vol. I (Woodbridge, 1998)

R. Lock (ed.), The Court Rolls of Walsham le Willows, 1351-99, Vol. I (Woodbridge, 2002)

Rotuli Hundredorum temp. Hen. III and Edw. I, Vol. II (London, 1818)

Suffolk Record Office (S.R.O.) HA504-3-3

\section{BIBLIOGRAPHY}

K. Altenberg, Experiencing Landscapes: a Study of Space and Identity in Three Marginal Areas of Medieval Britain and Scandinavia (Stockholm, 2003)

W.O. Ault, Open-Field Farming in Medieval England: a Study of Village By-Laws (London, 1972)

M. Bailey, A Marginal Economy? East Anglian Breckland in the Later Middle Ages (Cambridge, 1989)

J.S. Beckerman, 'Procedural innovation and institutional change in medieval English manorial courts', Law and History Review, 10:2 (1992), pp. 197-252

K. Biddick, 'People and things: power in early English development', Comparative Studies in Society and History, 32, 1 (1990), pp. 3-23

M. Bloch, French Rural History: an Essay on its Basic Characteristics, J. Sondheimer (trans.) (London, 1966)

C. Briggs, 'Court procedures, debt litigation levels, and rural credit provision in England, c. 1290-c. 1380', Law and History Review, 24:3 (2006), pp. 519-558

E. Britton, The Community of the Vill : a Study in the History of the Family and Village Life in Fourteenth-Century England (Toronto, 1977)

A. Buttimer, 'Social space and the planning of residential areas' in A. Buttimer and D. Seamon (eds), The Human Experience of Space and Place (London, 1980), pp. 21-54

P. Coss, Lordship, Knighthood and Locality: a Study in English Society c. 1180 - c. 1280 (Cambridge, 1991)

A. DeWindt, 'Peasant power structures in fourteenth-century King's Ripton', Mediaeval Studies, 38 (1976), pp. 236-267 
E.B. DeWindt, Land and People in Holywell-cum-Needingworth: Structures of Tenure and Patterns of Social Organization in an East Midlands Village, 1252-1457 (Toronto, 1971)

K.M. Dodd, The Field Book of Walsham-Le-Willows, 1577 (Ipswich, 1974)

R.A. Dodgshon, The European Past: Social Evolution and Spatial Order (Basingstoke, 1987)

C. Dyer, 'The social and economic background to the rural revolt of 1381' in R.H. Hilton and T.H. Aston (eds), The English Rising of 1381 (Cambridge, 1984), pp. 9-42

C. Dyer, Everyday Life in Medieval England (London, 1994)

D.P. Dymond, 'The parish of Walsham-Le-Willows: two Elizabethan surveys and their medieval background', Proceedings of the Suffolk Institute of Archaeology, 33 (1976), pp. 195-211

A. Everitt, 'Common land' in J. Thirsk (ed.) Rural England: an Illustrated History of the Landscape (Oxford, 2000), pp. 210-235

R. Faith, The English Peasantry and the Growth of Lordship (London, 1997)

P. Franklin, 'Politics in manorial court rolls: the tactics, social composition and aims of a pre1381 peasant movement' in Z. Razi and R. Smith (eds), Medieval Society and the Manor Court (Oxford, 1996), pp. 162-198

P. Freedman, Images of the Medieval Peasant (Stanford, 1999)

E.B. Fryde and N. Fryde, 'Peasant rebellion and peasant discontents' in The Agricultural History of England and Wales, vol. 3 (Cambridge, 1991), pp. 744-819

R. Guha, Elementary Aspects of Peasant Insurgency in Colonial India (Delhi, 1983)

H.E. Hallam, 'The life of the people' in H.E. Hallam (ed.) The Agrarian History of England and Wales, vol. 2, 1042-1350 (Cambridge, 1988), pp. 818-853

P.D.A. Harvey, 'Aspects of the peasant land market in England, thirteenth to fifteenth centuries', in P.D.A. Harvey (ed.) The Peasant Land Market in Medieval England (Oxford, 1984), reproduced in P.D.A. Harvey (ed.), Manors and Maps in Rural England, from the Tenth Century to the Seventeenth (Farnham, 2010), 9, pp. 7-19

S.H.A. Hervey, Suffolk in 1327, Being a Subsidy Return (Woodbridge, 1906)

O.G. Hill, The Manor, the Plowman, and the Shepherd: Agrarian Themes and Imagery in Late Medieval and Early Renaissance English Literature (London, 1993)

R. Hilton, Class Conflict and the Crisis of Feudalism: Essays in Medieval Social History (London, 1985) 
R. Jones and M. Page, Medieval Villages in an English Landscape: Beginnings and Ends (Macclesfield, 2006)

S. Kilby, 'Encountering the Environment: Rural Communities in England, 1086-1348' (unpub. Ph.D thesis, University of Leicester, 2013)

P.L. Larson, Conflict and Compromise in the Late Medieval Landscape: Lords and Peasants in Durham, 1349-1400 (London, 2006)

H. Lefebvre, The Production of Space (1991, Oxford, 2009)

E. Le Roy Ladurie, Montaillou: Cathars and Catholics in a French Village, 1294-1324, B. Bray (trans.) (London, 1990)

C. Lewis, P. Mitchell-Fox and C. Dyer, Village, Hamlet and Field: Changing Medieval Settlements in Central England (Manchester, 1997)

A. McLaughlin, Who Lived in Your House? People at Home in Early Walsham le Willows, Suffolk (Diss, 2007)

M. Mann, The Sources of Social Power, Vol. I: A History of Power from the Beginning to A.D. 1760 (Cambridge, 1986)

A.N. May, ' An index of thirteenth-century peasant impoverishment? Manor court fines', Economic History Review, 26:3 (1973), pp. 389-402

M. Müller, 'The aims and organisation of a peasant revolt in early fourteenth-century Wiltshire', Rural History, 14:1 (2003), pp. 1-20

M. Müller, 'Conflict and revolt: the Bishop of Ely and his peasants at the manor of Brandon in Suffolk c. 1300-81', Rural History, 23:1 (2012), pp. 1-19

S. Olson, A Mute Gospel, the People and Culture of the Medieval English Common Fields (Toronto, 2009)

Z. Razi, 'The struggles between the Abbots of Halesowen and their tenants in the thirteenth and fourteenth centuries', in T.H. Aston, P.R. Coss, C. Dyer and J. Thirsk (eds), Social Relations and Ideas: Essays in Honour of R.H. Hilton (Cambridge, 1983), pp. 151-167

T. Saunders, 'The feudal construction of space: power and domination in the nucleated village' in The Social Archaeology of Houses, R. Samson (ed.), (Edinburgh, 1990), pp. 181-196

T. Saunders, 'Class, space and "feudal" identities in early Medieval England', in W.O. Frazer and A. Tyrell (eds) Social Identity in Early Medieval Britain (London, 2000), pp. 209-232

P.R. Schofield, 'Peasants and the manor court: gossip and litigation in a Suffolk village at the close of the thirteenth century', Past and Present, 159 (1998), pp. 3-42 
P.R. Schofield, Peasant and Community in Medieval England, 1200-1500 (Basingstoke, 2003)

P.R. Schofield, 'Trespass litigation in the manor court', in R. Goddard, J. Langdon and M. Müller (eds), Survival and Discord in Medieval Society: Essays in Honour of Christopher Dyer (Turnhout, 2010), pp. 145-160

J.C. Scott, Weapons of the Weak: Everyday Forms of Peasant Resistance (London, 1985)

J.C. Scott, 'Resistance without protest and without organization: peasant opposition to the Islamic Zakat and the Christian tithe', Comparative Studies in Society and History, 29, 3 (1987), pp. 417-452

S.V. Smith, 'Towards a social archaeology of the late medieval peasantry: power and resistance at Wharram Percy', Journal of Social Archaeology, 9 (2009), pp. 391-416

D. Stone, 'The productivity of hired and customary labour: evidence from Wisbech Barton in the fourteenth century', Economic History Review, New Series, 50, 4 (1997), pp. 64-656

S.E. West and A. McLaughlin, Towards a Landscape History of Walsham le Willows, Suffolk, East Anglian Archaeology, 85 (1998)

C. Wickham, 'Gossip and resistance among the medieval peasantry', Past and Present, 160 (1998), pp. 3-24 
TABLE 1: TOTAL COURT CASES ASSOCIATED WITH THE LANDSCAPE AT WALSHAM, 1316-45 AND 1369-98

\begin{tabular}{|c|c|c|}
\hline & \multicolumn{2}{|c|}{ Number of Cases } \\
\hline & $1316-1345$ & 1369-1398 \\
\hline Cases of trespass on the demesne & 79 & 75 \\
\hline Cases of damage to the demesne & 874 & 273 \\
\hline $\begin{array}{lll}\begin{array}{l}\text { Unspecified } \\
\text { demesne }\end{array} & \text { trespass/damage } & \text { to } \\
\end{array}$ & 10 & 20 \\
\hline $\begin{array}{l}\text { Cases of Trespass on peasant land } \\
\text { (including common) }\end{array}$ & 88 & 19 \\
\hline $\begin{array}{l}\text { Unspecified trespass/damage to peasant } \\
\text { land }\end{array}$ & 72 & 54 \\
\hline Refusal to work & 81 & 30 \\
\hline Theft from demesne & 148 & 37 \\
\hline Total & 1,352 & 508 \\
\hline
\end{tabular}

Sources: Lock 1998; Lock 2002

Note: In many of the trespass cases initiated by tenants, the court does not appear to have recorded the initial plea, just the final judgement and corresponding court revenue. For example, in the case of several men damaging William Fenner's herbage, there is no mention of a trespass plea, but the case was judged by inquiry, and Fenner was ordered to pay $6 \mathrm{~d}$. to the lord from the resulting payment of damages (Lock 1998, p. 67) 
TABLE 2: GROUP ACTIVITY AT WALSHAM, 1316-1345 AND 1369-1398

\begin{tabular}{cccc}
\hline & $\begin{array}{c}\text { Number of potential } \\
\text { groups }\end{array}$ & Number of core groups & $\begin{array}{c}\text { Number of core groups } \\
\text { operating together four or } \\
\text { more times }\end{array}$ \\
\hline $1316-1345$ & 115 & 30 & 7 \\
$1369-1398$ & 42 & 9 & 2 \\
\hline
\end{tabular}

Source: Lock, 1998, pp. 29-286; Lock, 2002, pp. 100-205 
TABLE 3: FREQUENT TRESPASSERS, WALSHAM 1316-45 AND 1369-98

\begin{tabular}{|c|c|c|c|c|c|}
\hline \multirow[b]{2}{*}{ Tenant } & \multicolumn{2}{|c|}{ Number of incidents } & \multirow[b]{2}{*}{ labour refusals } & \multirow{2}{*}{$\begin{array}{c}\text { Number of } \\
\text { thefts against } \\
\text { the lord }\end{array}$} & \multirow[b]{2}{*}{ offices held } \\
\hline & $\begin{array}{l}\text { against the } \\
\text { lord }\end{array}$ & $\begin{array}{c}\text { against } \\
\text { peasants }\end{array}$ & & & \\
\hline \multicolumn{6}{|c|}{$1316-1345$} \\
\hline John Syre & 33 & 0 & 0 & 0 & 2 \\
\hline William Hawys & 24 & 2 & 3 & 3 & 2 \\
\hline Walter Osbern & 20 & 2 & 2 & 1 & 1 \\
\hline William Payn & 19 & 0 & 0 & 0 & 0 \\
\hline William de Cranmer & 11 & 0 & 2 & 1 & 1 \\
\hline \multicolumn{6}{|c|}{$1369-1398$} \\
\hline Peter Robhood & 27 & 4 & 2 & 1 & 0 \\
\hline Roger Prede & 19 & 0 & 0 & 0 & 0 \\
\hline John Frost & 8 & 0 & 0 & 0 & 1 \\
\hline William Swift & 8 & 0 & 0 & 0 & 0 \\
\hline
\end{tabular}


TABLE 4: MOST FREQUENTLY RECORDED LOCATIONS FOR TRESPASS AND

DAMAGE TO DEMESNE LANDS, WALSHAM, 1316-45 AND 1369-98

\begin{tabular}{|c|c|c|c|c|}
\hline \multirow[b]{2}{*}{ Location } & \multirow[b]{2}{*}{ Landscape Type } & \multirow[b]{2}{*}{ Manor } & \multicolumn{2}{|c|}{ Number of Incidents } \\
\hline & & & Individual & Group \\
\hline \multicolumn{5}{|c|}{$1316-1345$} \\
\hline Micklemeadow & Meadow & W & 37 & 4 \\
\hline Ladyswood & Wood & W & 28 & 2 \\
\hline Allwoodgreen & Arable & $\mathrm{HH}$ & 27 & 4 \\
\hline Hordeshawe & Arable / Meadow & $\mathrm{HH}$ & 26 & 4 \\
\hline Allwood & Arable / Meadow & $\mathrm{W} / \mathrm{HH}$ & 20 & 10 \\
\hline Currescroft & Arable & W & 19 & 0 \\
\hline Doucedeux & Arable / Legumes & $\mathrm{HH}$ & 17 & 1 \\
\hline Sheepcote & Arable / Legumes & $\mathrm{HH}$ & 16 & 1 \\
\hline Littlemeadow & Meadow & W & 15 & 4 \\
\hline Netherhawe & Arable / Legumes & $\mathrm{HH}$ & 15 & 0 \\
\hline Hamstale & Arable / Legumes & $\mathrm{HH}$ & 12 & 0 \\
\hline Launde & Wood & W & 11 & 4 \\
\hline \multicolumn{5}{|c|}{ 1369-1398 } \\
\hline High Hall & Close / Meadow / & $\mathrm{HH}$ & 42 & 4 \\
\hline & Arable & & & \\
\hline Ladyswood & Wood & W & 19 & 0 \\
\hline Hordeshawe & Arable / Meadow & $\mathrm{HH}$ & 16 & 2 \\
\hline Eastend & Arable / Meadow & $\mathrm{HH}$ & 11 & 1 \\
\hline Churchgate & Arable & W & 10 & 1 \\
\hline
\end{tabular}


TABLE 5: THE LOCATIONS OF ALL IDENTIFIED TRESPASS ON AND DAMAGE TO DEMESNE LANDS, WALSHAM, 1316-45 AND 1369-98

1316-1345

Micklemeadow

Ladyswood

Allwoodgreen

Hordeshawe

Allwood

Currescroft

Doucedeux

Sheepcote

Littlemeadow

Netherhawe

Hamstale

Oldtoft

Launde

Boynhawe

Sheephouse

Smallbrook

Ulviswell

at the Cross

Bluntesland

Cannonesbrook

Churchgate

Eastend

Hatchmere

Kembaldsland

Millmount

Millwong

Catherinescroft

Cowleswe

Dovehousewong

Fifteenacres

Fishponds

Fourteenacres

Brook Pasture
Aylenestoftrowe

Stonylond

Ayeldestoft

Angerhale

Lenerithsdel

Smithsway

Strondes

Westmill

Warren

Brouneswong

Gothelardslond

Shortlond

Southbrook

Boliskote

Calfpightle

Howistoft

Northrowe

Stubway

Nineacres

Prioursgate

Thirtyacres

Northhawe

Syke

at the Brook

at the Conynger

Burchardscroft

Newerowe

Nortonfield

Summerway

Woodway

Stantonfield

Tailorswong

1369-1398

High Hall

Ladyswood

Hordeshawe

Eastend

Church gate

Bluntesland

Hatchmere

Netherhawe

Walpolescroft

Allwood

Allwoodgreen

Burchardsway

Strondeswood

Micklemeadow

Oldtoft

Opposite the church

Strondesway

Angerhale
Boyhawe

Catherinescroft

Chirdilwell

Doucedeux

Easthall

Hallcroft

Hulver

Launde

Gravel Pit

Sheepcote

Thirtyacres

Fishpondfield

Sheepcoteclose

Stapleway

Brodedole

Gothelardes

Howestoft

Summerway

Total number of locations: 65 
TABLE 6: GROUP DAMAGE COMMITTED BY THE QUALM, TYPETOT AND PATEL FAMILIES AND THEIR NEIGHBOURS

\begin{tabular}{|c|c|c|c|}
\hline \multicolumn{4}{|c|}{ Date of Trespass } \\
\hline 2 Aug 1324 & 23 Nov 1335 & 28 Sep 1374 & 28 Sep 1374 \\
\hline William Clevehog & William Clevehog & Robert Man & Robert Man \\
\hline John de Cowlinge & John de Cowlinge & John Patel & John Patel \\
\hline Simon Peyntour & John Patel & Nicholas Patel & Nicholas Patel \\
\hline Cristiana Qualm & Simon Peyntour & Richard Qualm & Roger Prede \\
\hline Elias Typetot & Cristiana Qualm & Elias Typetot & Richard Qualm \\
\hline Rose Typetot & Richard Qualm & William Typetot & William Typetot \\
\hline Anne Typetot & Millicent Qualm & Robert Typetot & Elias Typetot \\
\hline & Elias Typetot & & \\
\hline & John Bolle & & \\
\hline \multicolumn{4}{|c|}{ Location of Trespass } \\
\hline Unknown & Hordeshawe & Hordeshawe & Hordeshawe \\
\hline
\end{tabular}

Source: CRWW 1, p. 94 and p. 193; CRWW 2, p. 119 


\section{FIGURE CAPTIONS}

FIGURE 1: WALSHAM PARISH c.1300-c.1399

FIGURE 2: THE FOCUS OF PEASANT DAMAGE TO THE DEMESNE AT WALSHAM, 1316-1321 AND 13261328

FIGURE 3: THE LOCATIONS OF THE HIGHEST INCIDENCES OF TRESPASS AND DAMAGE TO DEMESNE LANDS AT WALSHAM, 1316-1345

FIGURE 4: THE LOCATIONS OF THE HIGHEST INCIDENCES OF TRESPASS AND DAMAGE TO DEMESNE LANDS AT WALSHAM, 1369-1398

FIGURE 5: WILLIAM HAWYS' LANDHOLDINGS AND INCIDENTS OF TRESPASS AND DAMAGE, 1316-1345

FIGURE 6: PETER ROBHOOD’S TRESPASSES, 1376-1398

FIGURE 7: QUALM, TYPETOT, PEYNTOUR AND PATEL FAMILIES HOLDINGS AND DAMAGE TO DEMESNE LANDS, 1316-1398

\footnotetext{
1 Olson has also written on trespass, but does not see it as a political act.

2 I am grateful to Dr Stephen Mileson for the reference to this essay

3 West and McLaughlin identify three manors, however, records for Church House manor only survive between 1409-1508 and it does not form part of this study (West and McLaughlin 1998, p. 18)

${ }^{4}$ In the nineteenth century, Allwood Green was 900 acres (West and McLaughlin, p. 1)

5 The early Walsham Court General sessions dealt with breaches of the assize of bread and ale, aspects of law that usually formed part of the remit of the Court Leet, for which there was no franchise in Walsham ${ }^{6}$ In fact, it was usually the lord's steward who oversaw proceedings, although he did not adjudicate individual cases. At High Hall, it is suggested that the resident lord may have presided over the court there (Lock 1998, p. 7)

7 The highest number of surviving rolls for the Walsham court is five, in 1318, 1332 and 1338; similarly, in High Hall, four rolls survive in 1318 and 1327.

8 Lock, 1998: 1319-26 Walsham, 1320-7 High Hall; Lock, 2002: 1371-3 Walsham, 1366-71 High Hall, 1380-3 Walsham, 1387 and 1394 Walsham

${ }_{9}^{9}$ Hereafter, the term 'trespass' relates solely to infringements connected with Walsham's landscape, rather than the medieval legal meaning of the word.

10 There are 124 rolls between $1316-45$, and 57 between 1369-99

11 Land held in several was private in this period.

12 Although for an alternative view, in which it is argued that the planning of nucleated settlements may have been a more collaborative initiative, see C. Lewis, P. Mitchell-Fox and C. Dyer, Village, Hamlet and Field: Changing Medieval Settlements in Central England (Manchester, 1997)

13 The Observer, 13.9.2009; a similar sentiment was expressed by a displaced Masai herdsman in another article in The Observer, 6.9.2009

14 Bullimong is a mixed grain, usually beans and oats

15 Although see M. Müller, 'Peasant mentalities and cultures in two contrasting communities in the fourteenth century: Brandon in Suffolk and Badbury in Wiltshire (unpub. Ph.D thesis, University of Birmingham, 2001), pp. 292-6

${ }^{16}$ Although Saunders moderates his position somewhat in a later essay, suggesting more correctly that although lords attempted to regulate peasant spaces, they were not always successful (Saunders 2000)
} 
${ }^{17}$ Using West and McLaughlin's reconstructions, these maps show the furlongs in which trespass and damage occurred 